\title{
Episodic volunteer management at festivals
}

\author{
The case of Valletta Film Festival, Valetta, Malta
}

\author{
Lesley-Ann Dickson
}

\section{Introduction}

A film festival now opens every 36 hours somewhere in the world (Archibald and Miller, 2011, p. 249). As argued elsewhere (Dickson, 2017a), the extraordinary rate at which the number of festivals has increased signals a growing appetite for consuming film in event contexts and points to the increasing importance of multi-layered events in an experience-led economy. Likewise, over the last five years, there has been mounting interest in film festivals as objects of study by film and media scholars who consider them crucial sites for understanding film economies, politics and cultures. While film festivals have been considered through a variety of lenses and conceptualisations - imagined as religious orders (Bazin, 1955/2009), geopolitical networks (de Valck, 2007), open systems (Fischer, 2013), public spheres (Wong, 2016) and social constructions (Dayan, 2000), within this growing body of work there appears to be common agreement that film festivals are both exhibition circuits for the film industry and channels for cultural exchange. In this regard, film festivals oscillate between commercial, cultural and aesthetic agendas as "unique institution[s], which straddle art, commerce and governance" (Rhyne, 2009, p. 10). Yet, despite this commonality (balancing various imperatives), processes of differentiation drive film festival operations. The competitive nature of the global festival circuit means individual festivals must distinguish themselves from other events and effectively market their offerings as 'unique'. The pursuit for distinction is, however, no straightforward task and countless festivals have perished by failing to establish a distinct identity, and consequently, audiences and sustainable funding. Indeed, Alex Fischer (2013), points to Google in the foreword to his monograph on festival management, describing the search engine as a "graveyard for film festivals" that have been unable to carve out their place in the circuit (p. xi). Of central concern here are the possible reasons a festival might endure and flourish while others perish, specifically in relation to managerial and organisational practices.

This chapter presents a case study of a newcomer on the festival circuit, Valletta Film Festival (VFF). Launched in 2015 - some 80 years after the world's first film festival ${ }^{1}$, the event is in its infancy in festival terms. Nevertheless, in just three editions its organisers have achieved a steady increase in audience numbers, special guest attendance, and corporate sponsorship, all of which align with strategic plans for sustainability, expansion, and internationalisation (VFF 2015). In an attempt to shed light on VFF's emerging success story, the chapter draws on a range of materials (internal VFF reportage and evaluations, policy documentation), sources (interviewees and informal discussion with festival organisers, funders, volunteers) and fieldwork methods (interviews, volunteer questionnaire, on-site observation during VFF 2017). On the basis of this evidence the chapter will suggest that while there are a number of internal and external conditions that have aided the festival's emergence, its success (so far) is crucially related to effectual management practices within the organisation, specifically volunteer management and leadership.

\footnotetext{
$1 \quad$ It has been suggested elsewhere that the very first known film festival took place in Monaco in 1898. However, Venice is generally considered the first recurring film festival.
} 
Success is a ubiquitous term yet a multifarious concept. The varying notions of success have currency in a range of contexts in which film festivals are discussed and debated (industry, policy and academia). In an industry context, success has multiple meanings for the numerous agents involved in film festival operations - it manifests in different ways for different stakeholders. ${ }^{2}$ Nonetheless, a trawl online reveals a series of recurring "successdriven narratives" that appear to epitomise a more general discourse of success in relation to film festival events. Two core threads dominate these particular narratives. The first thread includes discussion around "how to achieve success" at film festivals, seemingly targeted at new talent (filmmakers, writers) seeking a fruitful film festival experience in terms of networking and deal-making. "How to" narratives include step-by-step guides (see Quadra, 2012; Edwards and Skerbeli, 2012; Gore, 2009) on surviving and succeeding for filmmakers, and online strategic tutorials such as the "Cannes Do[s]" for filmmakers that impart the secrets of festival "best practice"(see Edwards, 2017). The other thread is concerned with festivals themselves and focuses on what the markers of success might be for an event and its organisers. These narratives typically include "anecdotes of discovery" - for instance, when a festival has programmed a film or championed an emerging filmmaker, which/who have gone on to have critical and commercial acclaim or - even better - have received an Academy Award (see Kiang \& Lyttelton, 2017). Here, success is framed as something both surreptitious and complex; a multifaceted concoction that is "to be discovered". Indeed, Indiewire suggests that the "secret" to Cannes' success is a paradoxical approach that "simultaneously caters to high-minded, cultured sensibilities and plays up the much emptier conceit of a big, wild show" (Kohn, 2015).

Indeed, film festivals have been described as "fragile equilibrium[s]" where different, often competing, roles and agendas are acted out and upon by different festival stakeholders all vying for their own version of success (Dayan, 2000, p.45). For the festival organiser divergent stakeholders mean the management of divergent expectations. Rhyne (2009) suggests that successful multi-agenda management has fashioned "non-profit" as the dominant corporation status for festivals: "The non-profit model of film festival administration has provided an ideal laboratory through which to manage the interests of these stakeholders precisely because of the unique position of the third sector as a mediator between the state and the market" (p.20). As providers of cultural experiences and artistic showcases (often supported by public funding) and crucial nodes in the film industry (often with some degree of private sponsorship), festivals must evidence their value and accomplishments in both commercial and cultural terms. Given the primacy of evidencebased measures of value and impact, festival organisers' articulations of success tend to accentuate particular aspects of festival operations that serve to evidence their event as valuable, important and worthy of ongoing support. And so these articulations are principally quantitative (numbers and volumes): tickets sold; visiting talent; premieres; local audiences; international audiences; tourist expenditure; awards; international/national news coverage; reviews; sponsors. Fischer (2013) suggests that this results in a problematic scenario in which festival success becomes increasingly difficult to recognise because "the perceptions of resource providers becomes skewed towards particular indicators" (p.39). Getz and Andersson (2008) also warn that while festivals organisers often emphasise their market appeal and sales, the event's "fate will often be inextricably linked to managerial and organizational success" (p. 5).

2 For instance, success looks different for the emerging filmmaker in receipt of a prestigious audience award than it does to a festival organiser rejoicing in a $20 \%$ increase in ticket sales and international news coverage. 
In a scholarly context, festival success has been principally considered through macro lenses that seek to explain the proliferation of these events as thriving phenomena (see de Valck, 2007; Iordanova and Rhyne, 2009; Nichols, 1994; Wong, 2011). Nevertheless, a small pool of work has considered the micro-functionality of festivals - i.e. management practicalities of planning and delivering individual film festivals. Much of this work has centred on festival programming (see Marks 2004; Ruoff 2012; Czach 2004; Stringer 2008; Haslam 2004), which in many ways pertains to the centrality of product/artefact (in this case, film) and experience (i.e. premiere, special events) across the arts and culture sector. This also points to a perceived eminence of this operational area within festival management (above other areas such as marketing, box office, finance) and is suggestive that curators/programmers are at the top of the festival food chain. However, Fischer (2009) warns that film programming is only one aspect of a "larger and infinitely complex system of exhibition" (p. 153). In the first monograph dedicated to festival management, Fischer (2013) states that "successful film festival management is entirely based on the skilful manoeuvring of an event through a host of socially contrived conditions" ( $p$. xii). While warning against a "one-size-fits-all" approach, he offers an indicative typology of strategies for festival attractiveness: build alliances; get the timing right; location; having an identifiable function; encourage legitimate affiliations; offer participation-based incentives; exercise resource control; and join the club. This framework is useful for considering the ways in which VFF aligns with more established conventions of success, which have gained a steady footing in academia, industry and policy contexts.

\section{Environmental context}

The Valletta Film Festival is the brainchild of filmmakers, Oliver Mallia and Slavko Vukanovic. The pair recognised that Malta's rich cinema history (motion pictures were being screened in public halls in Valletta in the 1890s) and contemporary presence onscreen (Malta and its sister islands have been film locations for many films, including Gladiator, 2000) merited a national film festival (Bonello, 2015, p. 62). In fact, in the mid-2000s Malta was the only country in the European Union without its own feature film festival (Economou, 2017). However, the festival would only launch some 15 years after it was first conceived.

In his strategies for success framework, Fischer (2013) argues that timing is "a key consideration when film festival organisers are assessing the best possible conditions under which to conduct film festival operation" (p. 46). When the idea for VFF was initially discussed it was felt that it was not the right moment to launch the festival: "The climate was not ready for a festival, for many reasons: lack of values, lack of a particular identity that the festival should have, and our determination for it not to be a copy/paste of others". (Interview Oliver Mallia, VFF Founder, August 2017). In the years that followed those initial stirrings, both filmmakers went about other projects: Mallia set up the Malta Film Commission and produced a range of independent productions while Vukanovic launched and delivered the shorts film festival, Kinemastik (now in its fifteenth year) ${ }^{3}$. Yet, the idea for VFF endured and in 2013 they began planning Malta's feature film festival, setting up the umbrella organisation - Film Grain Foundation (FGF) - along with four other film industry professionals. As a non-profit, FGF would foster more film appreciation in Malta with the Valletta Film Festival acting as the foundation's flagship event, supplemented by a number of smaller film events in Malta and international pop-up events year-round. ${ }^{4}$

\footnotetext{
3 See www.kinemastik.org/

$4 \quad$ The Film Grain Foundation is registered with the Commissioner of Voluntary Organisations.

Registration Number VO/0949. See WWW.filmgrainfoundation.org/
} 
Another temporal consideration was which month to host the festival. A range of decisions predicated on the external environment drove the decision to hold the event in mid-June. In particular, June is viewed as a relatively slow month in the Maltese cultural calendar and would, therefore, allow the festival organisers to make VFF a "prime event" (Interview Bojana Dimitrovska, FGF Treasurer, May 2017). Moreover, June was considered to be a good month for film and guest availability because it is the only time in the year when there are few international festivals organised around the world (FGF, 2017, p. 3) Furthermore, in light of Malta's Mediterranean climate, June was selected for its warmer temperatures $\left(21^{\circ} \mathrm{C}\right.$ $25^{\circ} \mathrm{C}$ ), which would provide optimum conditions for open-air screenings in historic venues. Strategic location is also proposed as critical to a festival's success (Fischer, 2013). Indeed, de Valck (2007) argues that location is the most central element to a festival's identity, which is why it is almost always reflected in a festival's moniker. She argues that a festival distinguishes itself from other events using its location's climate, history and culture as markers of distinction. Marketing communications are then embedded with these characteristics and promoted to prospective participants via social media, printed marketing and press. The city of Valletta was chosen as the festival's home because it would offer a welcoming, inclusive and culturally rich festival experience on account of its size, rich heritage as a UNESCO World Heritage Site, and historical architecture, all of which would allow audiences to experience cinema in unique settings:

I really felt back then that, following the completion of the Renzo Piano city gate project, Valletta was finally becoming a city that could host a certain amount of international events; of a certain scale [...] Valletta is only 300-400 metres of a city, half a kilometre at maximum. I think it's unique in that sense. You are going to a small place and you're watching films, but you're also getting fully immersed into this culture, this heritage of different people that have passed through Malta and left their imprint on the island (Interview Oliver Mallia, VFF Founder, August 2017).

The cityscape regeneration was inextricably linked to Valletta's bid to become European Capital of Culture 2018 (ECC), which was confirmed in 2012. These developments also saw the Royal Opera House turned into an open-air theatre known as Pjazza Teatre Rjal, which would become one of VFF's flagship venues for big attraction films and galas. Furthermore, the ECC announcement set in motion a period of policy developments that would support and celebrate contemporary culture and creativity in Malta. In late 2015, the then Maltese government approved a new legal structure for Arts Council Malta (ACM) and a five-year strategy to put "arts and creativity at the heart of Malta's future" (ACM, 2015, p.9). The plan set out a range of strategic activities, training programmes, intergenerational arts activities, revision of secondary school curricula to enable students to experience a minimum of one professional artistic production, and tax deductions for arts donations. Part of this strategy was a commitment to the "professionalization of the cultural sector" (Interview Toni Attard, Arts Council Malta Director of Strategy, June 2017). In an attempt to develop Malta's presence in the global cultural economy and to develop the wider cultural ecology, the strategy set out a significant increase in public funding (39 percent) to support non-public sector NGOs involved in artistic and cultural output. The funding increase saw the introduction of Arts Council Malta's new funding programme, including the Cultural Partnership Agreement that would later become one of VFF's key (funder-based) alliances (Fischer, 2013). Thus, VFF's inception was set amidst an environment that was particularly conducive for those hoping to set up an international Valletta-based cultural event. Furthermore, the event's inception played a part in a "bigger picture plan" that sought to develop the arts and culture sector, enabled by a "governance system that allowed that kind of 
growth and development" (Interview Toni Attard, Arts Council Malta Director of Strategy, June 2017).

\section{Audacious ambition and quantifiable success}

Dayan (2000) notes that film festivals mostly spend time "answering questions about [their] self-definition, identity, and character" (p. 45). The precarious global circuit forces individual festivals to compete for a designated pool of new content, special guests and international press. As such, they must define their identifiable function and communicate participationbased incentives - promoting the benefits of participation to distributors, filmmakers, press, and audiences (Fischer, 2013, pp. 70-1). VFF's identity is particularly interesting as a newcomer. Rather than adopting the tentative approach commonly employed by new festivals - a focus on local community audiences, cautious use of resource, and gradual progress toward expansion and internationalisation, VFF organisers opted for a bold, ambitious and risky approach, launching with multiple category awards, international jury, premieres, and red carpets. Its founders provided 50 percent of the overall budget with the rest of the budget coming from mainly a public grant and private sponsorships. Thus, from the outset, the FGF team has been audacious in their actions and candid about their ambitions for internationalism and prestige, maintaining that the festival will be a "premiere film event in Europe" by its fifth anniversary in 2020 (VFF, 2015). In festival terms, this would signal high-speed accomplishment.

In terms of "recognised" successes, VFF has met a number of quantitative measures. Fischer (2013) suggest that film festivals are in constant competition with their former selves (previous editions) and that each new festival edition brings with it a new challenge - to surpass the measured outcomes of the previous edition (more tickets, more premieres, more guests, more coverage). In strategic documents, it is evident that VFF organisers primarily articulate achievements through past-present comparisons, which demonstrates skilled use of these established vocabularies of success. For instance, festival ticket numbers have increased by 34 percent since 2015, with an estimated increase of 39 percent in overall audience attendance when including free outdoor screenings. While the festival has reduced its number of films screened in line with its "quality over quantity" programming strategy, the number of strands has increased to include more in-competition and workshop/talent talk sections. The number of special guests has steadily risen over the three years - increasing from five guests to 32. Likewise, there has been an increase in the number of international accredited press attending the festival

A key milestone came in 2016 when the festival became one of 11 organisations named a "strategic partner" with Arts Council Malta and was awarded Cultural Partnership Agreement funding of $€ 150,000(2017-2019)^{5}$. There has also been a continual growth in the number of official and supporting partners, including, Audi, Transcripta Translations, Valletta 2018 and the Goethe-Institut, as well as a range of local project-specific partners. Fischer (2013) suggests building affiliations is a crucial strategy for film festivals because "previous participation validates future operation" (p. 58). These partnerships serve to bestow credibility on VFF and enhance its reputation and visibility, thus encouraging future participation from other partners, funders and sponsors.

Despite increasing financial support, VFF still operates on a very lean budget with no yearround, paid employees. The festival organising team work on various aspects of festival planning year-round but do so in a non-remunerated capacity. During festival time, the festival team increases significantly with approximately 70 episodic volunteers per edition. 
Indeed, the participation of these volunteers, as well as collaborating film professionals, is considered a significant marker of success by VFF organisers:

We also measure the success of our activities by the sheer number of volunteers and film professionals that return to work with us. Over the years we have amassed an impressive number of volunteers that work with us during the Festival week but also a large number of film professionals who are keen to get involved in our projects over the year. This to us is a concrete example of the relevance of the work we are doing (FGF, Action Plan, 2017, p. 10).

The volume of volunteer applications received by VFF - up to 250 per edition, is unprecedented in Malta. In fact, the festival's success in attracting and managing volunteers has been recognised by other cultural organisations. The most notable apprentice being Valletta 2018 whose organisers have sought guidance from VFF on how best to recruit and lead volunteers for the European Capital of Culture events programme - a solid indicator of the festival's success in this functional area.

\section{The absence of volunteers in film festival research}

An overarching concept underpinning this inquiry is that film festivals are "social constructions". They require the coming together of people (audiences, filmmakers, volunteers, funders, journalists) in order to function, and require those people to sociallyconstruct the festival's meaning and value both inside and outside of "festival time". Fischer (2013) argues that "the fact that film festivals require socially-based participation should not be viewed as merely a by-product of their functionality, but instead, as a critical, indeed intrinsic requirement of their actual operation" (p. 6). In this view, effective operations are linked to the social connectivity of film festivals and the effective management of a variety of festival stakeholders. This proposition is informed by Dayan's (2000) seminal ethnography of Sundance Film Festival in which he argues that film festivals, as social constructions, involve "multiple performances" by their participants who adhere to a range of "collective social rules"" (unwritten scripts, practices and social norms of the festival) (p. 45). Dayan focuses on a range of key participants and argues that the film festival is a fragile assembly that is dependent on the coming together of a range of people with varying motivations, agendas and priorities $^{6}$. This viewpoint is particularly meaningful to this case study because it moves away from a preoccupation with festival assets/objects/statistics (films, funding, marketplace, box office data) as being critical to the successful functioning of a festival to focus on the intrinsic value of festival subjects/people.

Interestingly, both Dayan (2000) and Fischer (2013) omit the same participant group from their conceptualisations: festival volunteers. However, these scholars are not alone in overlooking this particular interest group,$^{7}$ which is perhaps indicative of the position of volunteers in the aforementioned food chain. Indeed, in stakeholder theory, "influence/power" and "interest" are employed as qualifiers of priority and importance, and so volunteers regularly fall into a low priority group. In a festival context, individual volunteers have little power and (perceived) lower levels of investment due to the temporal nature of their engagements, however, collectively they are critical to festival operations and the social construction of the event, which may explain Getz and Andersson's (2008) counter view that volunteers and volunteer managers must be considered as primary stakeholders in

$6 \quad$ Dayan explores filmmakers, journalists and audiences.

$7 \quad$ Mark Peranson also overlooks volunteers in his model for 'interest groups and their importance', see

Peranson (2009, p. 28) 
festival operations. Furthermore, there are different types of festival volunteers, some of which occupy senior strategic roles. Indeed, many festival founders/directors are in fact volunteers, as Loist (2011) discusses in her article on festival labour:

Despite the (supposedly) prestigious status of film festival labour, most people working for festivals find themselves in insecure working conditions. The festival organizations are often precarious entities themselves, struggling for funding and usually operating on a bare minimum, with only very few full-time and year-round employees, some seasonal staff, in low pay or entry-level positions, and supported by interns and volunteers. This is true for most festivals (even at A-list events such as Berlin, Cannes and Venice) (p. 268-7).

Loist's (2011) view chimes with the argument that "running a film festival is a nearly masochistic undertaking that leaves anyone who attempts it open to the vagaries of time, money, and space (and other people)" (Fischer, 2013, p. xiii). ${ }^{8}$ Despite the problematic nature of non-remunerated labour - concerns shared by many festival managers who would prefer to be in a position to pay all staff (including themselves), the current and foreseeable reality is that unpaid labour is the lifeblood of film festivals. Festivals organisers must therefore, ensure that their event is appealing and incentivised for volunteer participants, and that volunteer management practices and processes are organised and supportive for participants. The ways in which festivals achieve this is of central interest here. This question is particularly relevant in the VFF case wherein the workforce is almost exclusively made up of volunteers, including all of the leadership team. Thus, for VFF, it is critical that its organisers attract a recurring flow of volunteers or the festival simply ceases to exist.

A useful body of work on volunteer management has emerged out of business management literature. This work suggests that the implementation of a systematic and structured volunteer programme, and the effective management of said programme, will ensure ongoing volunteer interest. Connors (2012) suggests that: "in today's complex society and era of rapid social and technological change, it is essential that formal programs and organizations engaging volunteers do so within a logical, holistic, systematic process that maximizes a volunteer's impacts on the program's/organisation's clientele being served while minimizing inconveniences and demands on the volunteer as an individual" (p. 50). As such, there is a preoccupation with devising functional methodologies for the volunteer manager/leader. A generous assortment of frameworks for effective volunteer resource management (VRM) exists, which consistently suggest a methodical and stage-led approach to the management of unpaid staff (see Stepputat, 1995). These models suggest that VRM shares many of the key tasks and practices found in human resources management, such as promotion, recruitment, selection and training. Many of these models are useful to varying degrees, however, the ISOTURE model (Boyce, 1971) proves most instructive to the VFF case because it incorporates volunteer engagement and leadership development. The model consists of seven volunteer management categories: identification, selection, orientation, training, utilisation, recognition, and evaluation. These categories each have related key tasks that are undertaken by the volunteer manager in order to effectively deliver volunteer programmes.

It is, however, crucial to acknowledge the "event" context of film festival volunteering because the spatio-temporal conditions of these events result in "fluctuating membership" from festival participants, including volunteers (Rüling and Pedersen, 2010, p.9). That is to

$8 \quad$ While a valid and much-needed area of debate, the political and ethical dimension of volunteerism is not the focus of this chapter. For more on the precarious conditions of festival workers, please refer to Loist (2011). 
say that volunteering in the festival context is short-term and falls into a specific category of volunteering, referred to as "episodic volunteering". Although no singular definition exists, the episodic volunteer is thought to be one who gives their time sporadically and only during special times of year (or events) or may even volunteer as a one-off activity (Macduff, 1995). Getz (1991) suggest that festivals require different volunteer management practices to lead short-term volunteers, a view shared by Stedman (2004). There is an argument that the ephemerality of events means that volunteer managers must focus heavily on episodic volunteer recruitment and foster a supportive volunteer community (Kim and Cuskelly, 2017). Cognisant of the temporality of the festival setting, there is a reluctance to compress VFF's volunteer management process into an established VRM model designed with longerterm volunteer programmes in mind. As such, the ISOTURE model functions as a guide for critically understanding the distinct management practices that operate in the context of an episodic volunteer setting, and developing an Episodic Volunteer Management Cycle (EVMC) model that may be applicable to other temporal volunteer contexts (Fig. 9.1)

Figure 9.1 Author's own episodic volunteer management (EVM) cycle, adapted from ISOTURE to fit the festival context. The process details the consecutive stages of the volunteer management process, however, it is presented as cyclical, as some of the volunteers will be redirected or retained for the next festival edition, while others will disengage

\section{Volunteer management: strategy and leadership}

In relation to the US context, Stedman (2004) argues that volunteer management has undergone a process of professionalization whereby the "vocation" of the volunteer administrator has become recognised as a profession in its own right, as opposed to an adjunct area of responsibility. In a UK context, a similar process can be seen in the charity sector with the creation of a range of occupations that fall within volunteer management, for example, volunteer development, volunteer programming, and volunteer recruitment. Conventionally in film festival operations, however, the organisational structure tends to adopt a model of coordination when it comes to volunteer management. In most cases, a volunteer coordinator - who is also usually a volunteer only with a greater degree of volunteering experience - is recruited to oversee the activities of the designated voluntary workforce. In these coordination roles, the remit is not to manage volunteers per se (coordinators have little authority) but to instead undertake a series of delegated tasks passed down from festival management such as coordinating volunteer schedules, communicating daily updates, and acting as a first point of contact. The volunteer coordinator might also be tasked with communicating various administrative and operational systems - such as health and safety - but in most cases, organisational process and policy administration will be the responsibility of a member of the management team whose role will involve a minor remit to oversee volunteer services. These managers will engage with the volunteer workforce at intermittent stages in the volunteer process, particularly at recruitment and selection stage and again during induction. In these cases, volunteer management is not integrated into the organisation's management and leadership structures, but operates within the context of other priority operational areas such as front-of-house management.

At VFF the picture is rather different. Rather than employing a dual approach to volunteer management, which includes a non-episodic manager responsible for key moments in the volunteer process (e.g. recruitment, selection, induction, scheduling) and an episodic volunteer coordinator who supervises volunteers during the delivery phase of the festival, VFF volunteers are managed continually by a designated volunteer manager who works on developing the volunteer programme year-round. This approach suggests that VFF organisers view volunteer management as a priority area for senior management, alongside 
programming and hospitality and events. The flat organisational structure of VFF also means there is one line manager between volunteers and the directors of the festival, and so volunteers are not substantially removed from the chain of command. One could argue that this ensures festival volunteers are more connected to the strategic vision of the festival and organisational goals, thus leading to a more healthy and cohesive organisation.

Stedman (2004) argues that volunteer managers can no longer be viewed within organisations as only managers or administrators. The role is now a "combination of manager, leader, educator, supervisor, evaluator and so on" (Stedman, 2004, p. 4). A distinct aspect of the VFF's volunteer management arrangement is that the volunteer manager sits on the festival's strategic leadership team at FGF. As a result, volunteer management is firmly on the strategic agenda, integrated as a priority area of festival management and integral to festival planning and development. In this regard, volunteers and volunteer managers are positioned as key stakeholders in festival strategy and operations. Moreover, as a member of the leadership team the volunteer manager is able to present strategic plans to professionalise the volunteer process, developing her own leadership competencies in the process.

There is suggestion that advocacy is a key aspect of the role of the volunteer manager (Stepputat, 1995). Advocating for volunteers and volunteerism at a strategic level ensures that the volunteer programme is an organisational priority and that any external shifts or trends (i.e. legislative changes affecting volunteerism, public opinion on volunteering and "unpaid" labour, decreasing volunteer culture) are swiftly brought to the decision-making table. As example, in its first year VFF leaders faced the challenge of attracting Maltese people to volunteer at the festival. Since then, and adopting an integrated approach that understood festival branding and volunteer recruitment as mutually supportive strategies, the festival has expanded the visibility and presence of the event throughout Valletta and Malta via traditional marketing methods (e.g. posters, banners) and enhanced web presence and online branding. This activity has increased the festival's visibility and in turn generated wider awareness of the volunteer programme in Malta:

I had a lot more Maltese volunteers involved this year or enquiring, asking me questions, sending me emails. So, I think they are starting to get involved. They are starting to understand how cultural events work. That there is something they can take out of it. It's not just about giving. You give and take also. So, I think our approach is working, and they are realising that slowly. (Interview Alev Blackburn, VFF Volunteer Manager, August 2017).

Likewise, there are plans to establish a strong awareness amongst students in Malta, promoting the event to them as both an audience and as prospective volunteers. The volunteer manager has leadership buy-in to deliver a campaign that will directly target organisations that represent students (including academic institutions) to encourage more volunteer engagement from this demographic. This initiative is now embedded at strategic level, and features in the festival's Cultural Partnership Agreement Action Plan for 2017-18, which was submitted to Arts Council Malta (see FGF, 2017, p. 11).

\section{Episodic volunteer management: process and practice}

Connors (2012) defines volunteer management as "a systematic and logical process of working with and through volunteers to achieve an organization's objectives in an everchanging environment" (p. 53). Despite its newcomer status, VFF has shown considerable progress in the development of a volunteer resource management system that aligns with the needs of the festival, particularly when compared to other areas of functional management 
that are, arguably, less developed. ${ }^{9}$ The festival's progress in this area is evident when applying volunteer management frameworks, which propose a multi-staged, systematic approach to managing volunteer workforces. As noted, there are a variety of "volunteer resource management" models that highlight the need for a pragmatic approach to volunteer administration, management and leadership (albeit through varying terms and acronyms). In applying one of the most notable professional volunteer models, ISOTURE (Boyce, 1971), it becomes clear that VFF has very speedily introduced a system for the volunteer programme that shares many of the key management stages within VRM frameworks.

The first stage in the volunteer management process according to the ISOTURE framework is the identification stage, which involves a series of research processes in which the volunteer manager must identify, define and understand the volunteer needs of the organisation, as well as the benefits on offer for volunteers and their motivations for applying. At this stage, the volunteer manager addresses the needs of the festival in terms of the number of volunteers required, functional areas in need of support, and types of job roles. The identified needs are then cleared with the leadership team after which the process of drawing up specific volunteer roles and creating job descriptions and promotional materials commences.

Rather than advertising a generic volunteer programme, VFF develops descriptions of specific volunteer areas and job roles, as well as outlining the key characteristics of ideal volunteers. These specificities are articulated to prospective volunteers from the first point of promotion when the "call for volunteers" is launched in February of each year via a video presentation. The promotional presentation features on the VFF website and is pushed out via targeted (contacting previous volunteers, promoting the programme to local film schools) and non-targeted marketing (via social media channels). The presentation breaks down volunteer roles available, time commitments, key duties, and suitability for the post. Roles are also categorised by functional areas of festival operations (see Table 9.1). The benefit of clearly communicating volunteer options to potential participants is that it allows them to apply for a specific area in line with their interests, skill-set or availability. Ensuring a good level of clarity from the earliest moments of volunteer engagement serves to maximise engagement throughout the volunteer process. Moreover, it ensures that volunteer-festival relations align volunteer motivations (why they are applying for a particular post) with organisational needs (the roles made available) from the outset. Rehnborg and Moore (2012) argue that this is critical in optimising volunteer engagement levels:

With intentional planning and vision setting, effective volunteer management can maximise volunteer participation; manage diverse volunteer interests and resources [and] ensure voluntary labour connects with organization's strategic goals. To reach this goal, organisations must begin by acknowledging the diversity of roles and motivations in their volunteer workforce (p. 103).

Alongside online promotion, the launch of the volunteer programme is also marked by an information event, which takes place in Valletta. An online version is made available to international volunteer prospects. The purpose of this event is to promote the various volunteer roles on offer and the benefits of working for VFF, but mostly these events function as an opportunity for the volunteer manager to motivate prospective volunteers to formally apply to the programme:

In the information session, we give information about the festival itself, what's involved, provide some key information regarding to that specific year, and talk about volunteering, which areas we need volunteers for and what kind of duties they 
involve. We then discuss what kind of benefits they will get from those duties to encourage them to come work with us! (Interview Alev Blackburn, VFF Volunteer Manager, August 2017)

Table. 9.1. Shows the functional areas where volunteers are appointed. Also shows the types of roles and tasks, as well as the varying volunteer timelines and applicant characteristics. This information is provided in a promotional presentation available at www.vallettafilmfestival.com, see https://vimeo.com/210809738

\begin{tabular}{|c|c|c|c|c|}
\hline Functional Area & Roles & Timeline & Tasks & Suitable Person \\
\hline Production & $\begin{array}{l}\text { Office } \\
\text { Assistants, } \\
\text { Front-Desk } \\
\text { Operations }\end{array}$ & $\begin{array}{l}\text { April } \\
\text { June }\end{array}$ & $\begin{array}{l}\text { Assisting organisers } \\
\text { with enquiries, } \\
\text { administration and } \\
\text { festival operations. }\end{array}$ & $\begin{array}{lr}\begin{array}{l}\text { Dynamic, } \\
\text { responsible } \\
\text { organised }\end{array} & \begin{array}{r}\text { highly } \\
\text { and }\end{array} \\
\text { individuals. } & \text { Those } \\
\text { who wish to pursue } \\
\text { a career in } & \text { event } \\
\text { organisation, } & \text { film } \\
\text { production } & \text { or } \\
\text { cultural } & \\
\text { management. } & \end{array}$ \\
\hline Hospitality & $\begin{array}{l}\text { Guest } \\
\text { Relations, } \\
\text { Venue } \\
\text { Assistant }\end{array}$ & $\begin{array}{l}\text { June (must } \\
\text { be available } \\
\text { throughout } \\
\text { the festival) }\end{array}$ & $\begin{array}{l}\text { Supporting the } \\
\text { organisers in } \\
\text { managing the venues } \\
\text { and different } \\
\text { screenings and } \\
\text { events. Taking care } \\
\text { of guests attending } \\
\text { the festival. }\end{array}$ & $\begin{array}{l}\text { Anyone interested in } \\
\text { operational roles and } \\
\text { guest relations. }\end{array}$ \\
\hline Technical & $\begin{array}{l}\text { Technical } \\
\text { Assistant }\end{array}$ & $\begin{array}{l}\text { June (must } \\
\text { be available } \\
\text { throughout } \\
\text { the festival) }\end{array}$ & $\begin{array}{l}\text { Supporting the } \\
\text { technical tea in } \\
\text { setting up and } \\
\text { running the various } \\
\text { audio-visual, and } \\
\text { other technical, set } \\
\text { ups required at the } \\
\text { festival. }\end{array}$ & $\begin{array}{l}\text { Anyone interested in } \\
\text { a career in film, } \\
\text { sound, } \\
\text { projection. }\end{array}$ \\
\hline $\begin{array}{l}\text { Marketing \& } \\
\text { Communications }\end{array}$ & $\begin{array}{l}\text { Content } \\
\text { production }\end{array}$ & $\begin{array}{l}\text { April } \\
\text { June }\end{array}$ & $\begin{array}{l}\text { Assisting organisers } \\
\text { with creating } \\
\text { promotional material } \\
\text { (web, } \\
\text { photography, print, } \\
\text { videography) and } \\
\text { disseminating it to } \\
\text { the general public. }\end{array}$ & $\begin{array}{l}\text { Anyone interested in } \\
\text { a career in } \\
\text { marketing public } \\
\text { relations, journalism } \\
\text { and sales. }\end{array}$ \\
\hline
\end{tabular}


The selection stage of the VRM process at VFF is triggered when - having seen the promotional materials or/and attended an information session - applicants complete and submit a volunteer application form. The online application marks the first stage in the selection process, providing the VM with basic information on the application, including their experience and preferred functional area (VFF, 2017b). ${ }^{10}$ The form allows the volunteer manager to quickly begin considering how each volunteer might fit with the needs of the organisation.

Although volunteer preference (the area they would prefer to work in) is important, for the volunteer manager a key consideration is the amount of time that the applicant can dedicate to the festival. As such, the application form features a pointed question relating to the number of hours the applicant is willing to commit. Although potentially problematic in its use of "available hours" as a qualifier for the applicant's enthusiasm" ${ }^{11}$, this question does allow the volunteer manager to begin considering which applicants might be suitable, or unsuitable, for which roles depending on the needs of each functional area. Thus, applicant availability - in terms of number of hours, period of volunteering, and times/days available (all day, part days, week days, weekends) - drives the first selection stage:

Availability is the key at this stage. In specific areas, for example, in the production office I tend to need volunteers who can provide regular hours and a higher number of hours. I'm looking for, realistically, 40 hours or more. It's because [...] we need our volunteers there quite regularly every day, carrying out tasks as you would in any production office. [...] For photography and technical, again, I like to get the same people for regular hours and days. For social media, we have some sort of regular hours. [...] However, for ushering, that's way more flexible. I don't need as much regularity and so I can have people who can commit fewer, irregular, hours. (Interview Alev Blackburn, VFF Volunteer Manager, August 2017)

At this point, standard recruitment criteria guided the volunteer manager's decision-making process: 1) the candidate's hard and soft skills 2) specific experience relating to their chosen role 3) previous volunteer/VFF experience 4) education. Following this preliminary stage of selection, the volunteer manager then makes direct contact with each individual whose availability and area of interest are conducive. This contact is made via phone, video call or face-to-face meeting depending on where the applicant is based and what position they have applied for (for instance, the volunteer manager is keen to personally meet those interested in guest relations as they will be client-facing). Such direct contact also provides an opportunity for the volunteer manager to get a sense of the applicant's general demeanour, disposition and fit, and to consider their motivations for volunteering and their passion for both their specific area of interest and cinema exhibition and festival management more broadly:

\footnotetext{
10 Data captured in the application form: personal information (name, age, nationality), contact details (email, phone number) skills, experience and education (languages spoken, qualification level, past VFF volunteer,), preferred volunteer area (production, technical, marketing, hospitality and events), experience in relation to preferred area, and availability (morning/afternoon/weekend, and number of hours).

11 The question posed is: 'How much time can you dedicate to VFF?' with the following available answers 1) Not too much, maybe 20 hours, 2) I am eager, I can do 40+hours, 3) I love VFF, will gladly put in over 60+hours, 4) VFF is my life, I will dedicate all my free time to it. It is evident that this question is designed to equate higher number of available hours with dedication and commitment. One could argue that this problematic, and that it may be off-putting to potential volunteers who have a lesser degree of availability due to other commitments, but are as equally keen as other volunteers with more free time.
} 
I like to see how much they are interested in that area. I wouldn't like to schedule anyone in an area that they have no interest at all. That just wouldn't work. So, for me it's very important to see that interest and passion about it before I make a decision. (Interview Alev Blackburn, VFF Volunteer Manager, August 2017)

The selection process also considers the range of volunteer profiles and the volunteer manager makes efforts to recruit a diverse volunteer workforce:

I recently had an Irish volunteer, he was over 65 years old, and had arranged his holiday for the festival dates. [...] I'm coming from a filmmaking background but I also used to work for some charity organisations so, for me, diversity and inclusiveness are very important. There is no discrimination because of age, sex or any other reason. For me, everyone should be given the opportunity if they have availability. Everyone has potential; everyone has different talents and skills. (Interview Alev Blackburn, Volunteer Manager, August 2017)

Once selection has taken place in spring the process moves into a period of hiatus - a countdown to the event. This can often mean 2-3 months of silence between a volunteer appointment and the festival. In HRM recruitment, this period involves numerous email or telephone exchanges with appointed candidates to exchange contracts, enter salary negotiations, and provide induction materials etc. In the context of episodic volunteer programmes, these exchanges are not compulsory. However, there is a risk of the episodic volunteer becoming disengaged by the organisation entering into an extended "no contact" period. And so, the process moves into what I term preservation and inclusion whereby the volunteer manager is tasked with preserving the initial motivations of the volunteer through interim communications. At VFF the volunteer manager maintains regular contact with selected volunteers to maintain their enthusiasm and to instil excitement in participants as festival developments emerge - for instance, updating them on confirmed VIP guests and premieres. This also provides a sense of pre-event inclusion wherein volunteers feel part of the festival operations both inside and outside of festival time.

In the week leading up to the festival, the volunteer manager moves into the next stage, orientation and training, in which volunteers are familiarised with the event and their specific role and designated duties. The orientation element of the programme centres on familiarising volunteers with VFF practices, processes, people and places. This is the point at which the volunteer manager explains how volunteers fit into the overall organisation as "an integral part of the VFF team" (VFF, 2017a, p. 1). The volunteers are then integrated into the wider VFF team - acquainted with the senior management team and other members of staff, introduced to the various VFF resources (e.g. central databases, shared storage drives) and familiarised with VFF festival sites (e.g. office, venues, breakout) - at varying stages depending on volunteer roles and the location of the applicant. For instance, for production and marketing volunteers, orientation will take place in April. For others, such as hospitality staff, it is likely to take place in the few days prior to the festival.

Training presents a more pressing challenge for the managers of episodic volunteers, as the temporal dimensions of the festival mean that the entire workforce is not on-site in the same moment. For instance, in 2017, 32 percent of volunteer survey respondents were non-Malta residents (Questionnaire VFF Volunteers, September-December 2017). These volunteers were self-funding their international travel to come to the festival in order to volunteer. Thus, scheduling advanced in-person training in these circumstances is problematic. To counter this, VFF delivers online training in April and May for those selected for the volunteer programme. All participants - local and international - are expected to report for induction 
with the volunteer manager in the week leading up to festival launch. From 2018, volunteers will also be provided with a handbook, containing all essential information, including rewards and volunteers code of conduct. This material is imbued with what Dayan (2000) refers to as the "collective social rules" of film festivals. As representatives of the organisation, volunteers are expected to adhere to these rules, which include: "don't forget to smile and have fun" (VFF, 2017b, p.1)

The utilisation phase allows volunteers to put their existing skills and new knowledge (from VFF training) into practice. At VFF, in addition to generic training, volunteers are provided with role-specific training in their respective functional area. It is unfeasible for the volunteer manager to directly supervise all volunteer activities given the spread of the festival across the city. As such, the volunteer manager utilises delegation to provide volunteers with the chance to manage their task-load independently. The provision of delegated workload and lack of micro-management appeared to be welcomed aspects of the volunteer management process by volunteers themselves:

- The volunteer manager was always on hand to assist with queries, but she trusted me to do what I was supposed to do without checking on me too often.

- We were given a lot of freedom and trust, no controlling or demanding.

- Management was balanced and appropriate.

- The volunteer leader always provided me with the necessary support and instructions. about tasks, and was ready to help me if necessary in case of difficulties

- I was given a general induction and a more specific briefing on how to do my tasks, and then I was left to work independently.

(Questionnaire VFF Volunteers, September-December 2017).

In VRM models, recognition, involves the acknowledgment and reward of positive volunteer effort. At VFF, recognition is formally given through reward wherein volunteers are able to access parties and screenings depending on their input (i.e. number of hours). In most cases, volunteers are given an all-access festival pass, which allows them access to all screenings. Beyond this, recognition is also given through informal feedback and thanks by the volunteer manager and senior management team. During earlier stages (preservation and inclusion, utilisation), all of the senior managers focused on building relationships with volunteers and welcoming them into the festival community. Building such a positive volunteer-manager relationship throughout the process means that informal recognition and constructive feedback are of more value to volunteers. It also creates an open dialogue and culture of approachability in which volunteers feel they can articulate a desire to diversify tasks, take on more responsibility or suggest improvements.

The development of a healthy volunteer-manager relationship also affects the Evaluation process, which requires participants to complete written feedback on their volunteering experience. Although a new development in the VRM process, the festival volunteer manager has deemed evaluation as a critical phase in the volunteer cycle because it not only provides evidence for developing and improving the volunteer programme but also brings the period of volunteering to a close. However, I propose that there are three modes of closure in the event volunteering context, which relate to an seventh stage in the EVMC (see Fig. 9.1). Drawn from the GEMS model (Culp et al, 1998) of volunteer management, this last stage in the cycle is redirection, retainment or disengagement With episodic volunteering, some sort of closure must be achieved to terminate volunteer commitment at the end of the event; however, given the recurrent nature of festivals, there is an opportunity for the volunteer process to resume the following year for some participants. The evaluation phase enables the volunteer manager to identify those who wish to retain a relationship with VFF by way of communication with the volunteer manager at key moments in the festival's year-round cycle 
(notably when the volunteer programme opens the following year). For instance, 72 percent of volunteer questionnaire respondents indicated a desire to volunteer for VFF again, and, therefore, potentially would fall back into the EVM cycle. It also allows those who wish to end their commitment and relationship with the organisation a chance to disengage or for the volunteer manager to disengage with those deemed unsuitable for future volunteer opportunities. Here, the volunteer manager also has the opportunity to reward volunteers whom have excelled in their roles by redirecting them to a role with more responsibility the following year or by providing a professional statement to support their redirection into another organisation as a volunteer or as paid employee.

\section{Volunteer Management: Organisational Culture}

Earlier in the chapter, I discussed the absence of volunteers in conceptualisations of film festival and their respective participants, stakeholders, and social actors. In defence of Fischer (2013), he makes the distinction that film festivals are "served" by seven external groups and, thus, could argue that volunteers are imagined as internal to festival operations. Certainly VFF's internal documentation and approach to managing their episodic volunteers is suggestive of an organisation that imagines the volunteer as being integral to the festival team, somewhat corroborating a view of the volunteer as 'festival insider'. As I have discussed elsewhere, the status of "festival insider" has currency in the world of film festivals and is used as a promotional tool for attracting participants - in fact, Sundance Film Festival's volunteer programme calls on prospective participants to become 'festival insiders' (Dickson, 2017b). However, festival volunteer participation is rewarded with more festival participation, which shifts them into a different type of participant - as an audience member. As such, during festival time, volunteers alternate between being festival workers and festival audiences. In light of the duality, one could argue that the festival volunteer occupies a central position wherein they socially construct different meanings of the festival as both insider/worker and outsider/audience (see Fig. 9.2).

Figure. 9.2 Visual representation of the central position that festival volunteers occupy in the context of film festival management - as both valuable members of the festival team but also as participants whom are served by the festival team. In addition to the audience experience, volunteers' festival experiences should be of central concern to festival managers

Given that they occupy this complex participant position, volunteers become hugely important festival critics, able to review their festival experience from two perspectives. As such, VFF's strategic aims focus not only in creating a unique festival experience for audiences, but also for episodic volunteer participants:

I always tell them that it's very important for me that they enjoy the festival as well. It's not just helping other people they must enjoy it themselves. That's really, really important. I try to give that message all the time. Go see the films and enjoy what the festival has to offer (Interview Alev Blackburn, VFF Volunteer Manager, August 2017).

Indeed, a significant factor that shapes the volunteering experience at VFF is the organisational culture, which values and celebrates its volunteer workforce and encourages volunteers to immerse themselves in the festival and its multiple communities. Significant indicators of the celebratory nature of volunteerism in the VFF context is apparent in how open the festival is in discussing its volunteer support, and crediting those who willingly give their time. For instance, a list of volunteers is present on the festival's website homepage. 
Likewise, at the closing film each year, volunteers are asked to join the leadership team on stage to allow them, and the audience, to give thanks for their efforts and commitment to the festival (see Image. 9.1)

\section{<INSERT DICKSON CASE STUDY IMAGE 9.1 HERE>}

Image 9.1. Volunteers join the organising team on stage at the close of the Second Valletta Film Festival in 2016. Image courtesy of Valletta Film Festival. Photo credit: Ali Tollervey.

Furthermore, while there is a visible hierarchy at VFF - a small number of senior leaders there is a distinct lack of authoritarian rule at the festival. This is based on the festival's principle that even the senior team should get their hands dirty: "You see us all [festival leadership team], hands on deck, arranging venues, cleaning the seats. [...] You can often see me putting out chairs, removing barriers, arranging stuff. There is no hierarchy" (Interview Oliver Mallia, VFF Founder, August 2017).

However, there is also a sense that volunteers are encouraged to do more than the menial tasks. This in many ways connects back to early discussions about the lack of micro management in the operational management practices of VFF, in which volunteers are allowed to use their initiatives:

What is key is the treatment of volunteers during the festival. This is a crucial thing because as we professionalise it will become more like people management. I firmly believe you should empower people in the workplace. You have to give them the space where they can do something and they can be of use to the project. I think we are doing our upmost to empower volunteers. (Interview Oliver Mallia,VFF Founder, August 2017).

The non-hierarchical structure of the festival - which sees all staff are working towards the same goals - is driven by a passion for film. This means creating an environment that makes volunteers "feel like they belong to something". Indeed, the spirit of an inclusive festival community is underpinned by its founder's belief that creating a festival is a collaborative effort, as Mallia notes:

Valletta Film Festival is not just about Oliver, or Slavko, or about any other member of the management team. It's about a group of people. And part of that family is also the volunteers. It's a collective effort. It's very much like a film because a film cannot be made by just the director. To make a good film requires a good producer, good actors, good cinematographers, good costume designers, same as a festival. For a festival you require team work, collective effort. I can't do a festival on my own. (Interview Oliver Mallia, VFF Founder, August 2017).

Thus, while a much less quantifiable aspect of festival success, values of inclusion and appreciation constructs a culture that celebrates the efforts of all participants, and values volunteers as both festival insiders but also as festival audiences - placing importance on them having a unique festival experience.

\section{Conclusion}

Getz (2008) suggests that notions of failure or permanence have subsumed discussion of festival achievements. In many ways, the adaptive nature of film festivals dictates an approach that considers the achievements of any festival in relation to not only existing 
practices and accomplishments, but also ongoing developments and evolutions. This approach is most useful when looking at a festival in its formative years.

Certainly, Valletta Film Festival's organisers have achieved a number of successes that align with established indicators and strategies for success. However, considering less quantifiable features of festival operations has proved useful in understanding the internal management successes that are critical to the survival of the festival. In its short existence, VFF organisers have implemented a volunteer management structure that positions the volunteer programme firmly on the strategic agenda, allowing for swift responses to shifts in volunteer supply and demand, and embedding volunteer evaluation. Likewise, the volunteer manager has developed an in-progress process that aligns with established models of volunteer management. Lastly, the event's organisers have cultivated a non-hierarchical organisational culture that places people (passions, motivations, experiences) at the centre of its efforts. Thus, the central proposition is that VFF's emerging success story is more complex than festival success narratives dictate -“more premieres, more tickets, more guests, more funding" does not adequately explain a festival's accomplishments. As such, it is crucial to look at the internal management activity at festivals if we are to fully comprehend the multiple practices and process that come together to successfully deliver these cultural events. In doing so, we will enhance our understanding of the sustainability and fragility of these festivals, and confront the uniformed expectations of "festival success" that have formed the dominant discourse of policy, academic and industry narratives

\section{Bibliography}

ACM. (2005). CREATE2020 Strategy 2016-2020. Arts Council Malta.

Archibald, D., \& Miller, M. (2011). The film festival dossier: Introduction, Screen, 52(3), 274-279.

Bazin, A. (2009). The festival viewed as a religious order. In R. Porton (Ed.) Dekalog 3: On Film Festivals. (E. Bickerton, Trans.). London: Wallflower Press. (Original work published in 1955).

Bonello, G. (2015) Early visions: The presence of film-makers in early 20th century Malta. In J.P. Borg \& C. Cauchi (Eds.) World Film Locations: Malta. Bristol, UK: Intellect.

Boyce, M. (1971) A Systematic Approach to Leadership Development. Washington, DC: USDA.

Connors, T. D. (2012, 1995). The Volunteer Management Handbook: Leadership Strategies for Success (2nd edition). New York, NY: Wiley.

Culp, K., Deppe, C., Castillo, J., \& Wells, B. (1998) The G.E.M.S model of volunteer administration. Journal of Volunteer Administration, 26(4), 36-41.

Czach, L. (2004). Film Festivals, programming, and the building of a national cinema. The Moving Image, 4(1), 76-88.

Dayan, D. (2000). Looking for Sundance: The Social Construction of a Film Festival. In I. Bondebjerg (Ed.) Moving Images, Culture and the Mind. Luton, UK: University of Luton Press.

de Valck, M. (2007). Film Festivals: From European Geopolitics to Global Cinephilia. Amsterdam: Amsterdam University Press. 
Dickson, L. (2017a) 'Beyond film' experience: Festivalizing practices and shifting spectatorship at Glasgow Film Festival. In S. Atkinson and H.W. Kennedy (Eds.), Live Cinema: Cultures, Economies, Aesthetics. London: Bloomsbury.

Dickson, L. (2017b) Insider/outsider positions at Glasgow Film Festival: Challenges, issues and opportunities in industry-partnered ethnographic research. In A. Vallejo and M.P. Peirano (Eds.), Film Festivals and Anthropology. Cambridge: Cambridge Scholars Publishing.

Economou, V. (2017). Oliver Mallia - Directory, Valletta Film Festival. Cineuropa. Retrieved from www.cineuropa.org/it.aspx?t=interview\&l=en\&did=330703.

Edwards, Rona (2017) RONA'S REEL TAKE: Tips for a Successful Film Festival Experience, Part 1. Retrieved from www.scriptmag.com/resources/film-festivals/tips-forsuccessful-film-festival-experience-part-1.

Edwards, R., \& Skerbeli, M. (2012) Complete Filmmaker's Guide to Film Festivals: Your All Access Pass to Launching Your Film on the Festival Circuit. California, USA: Michael Wiese Productions.

FGF (2017) Film Grain Foundation: CPA Action Plan 2017-2018. Film Grain Foundation. Internal document.

Fischer, A. (2013). Sustainable Projections: Concepts in Film Festival Management. St Andrews, UK: St Andrews Film Studies.

Fischer, Alex (2009) Conceptualising Basic Film Festival Operation: An Open System Paradigm. (Doctoral dissertation). Retrieved from http://epublications.bond.edu.au/theses/28/.

Getz, D., \& Andersson, T. D. (2008). Sustainable Festivals: on becoming an institution. Event Management, 12, 1-17.

Getz, D. (1991). Festivals, Special Events, and Tourism. New York: Van Norstrand Reinhold.

Gore, C. (2009). Chris Gore's Ultimate Film Festival Survival Guide (4th ed.). New York: Watson-Guptill.

Haslam, M. (2004). Vision, Authority, Context: Cornerstones of curation and programming. The Moving Image, 4(1), 48-59.

Iordanova, D., \& Rhyne, R. (2009). Film Festival Yearbook 1: The Festival Circuit. St. Andrews: St. Andrews Film Studies.

Kiang, J., \& Lyttelton, O. (2017). The Sundance Film Festival's 20 biggest Oscar success stories. Retrieved from http://theplaylist.net/sundance-film-festivals-20-biggest-oscarsuccess-stories-20170123/\#cb-content.

Kim, E., \& Cuskelly, G. (2017). A systematic quantitative review of volunteer management in events. Event Management, 21, 83-100. 
Kohn, E. (2015). The secret to the success of the Cannes Film Festival. indiewire.com. Retrieved from www.indiewire.com/2015/05/the-secret-to-the-success-of-the-cannes-filmfestival-62039/.

Loist, S. (2011). Precarious cultural work: About the organization of (queer) film festivals. Screen, 52(2), 268-273.

Macduff, N. (1995). Volunteer and staff relations. In T. Connors (Ed.), The Volunteer Management Handbook. New York, NY: Wiley.

Marks, L. (2004). Film programming dossier. The Moving Image, 4(1), 1-88.

Nichols, B. (1994). Global image consumption in the age of late capitalism. East-West Film Journal 8(1), 68-85.

Peranson, M. (2009). First you get the power, then you get the money: Two Models of Film Festivals. In R. Porton (Ed.) Dekalog3: On Film Festivals. London: Wallflower Press.

Quadra, S. (2012) 7 Steps to Film Festival Success. Self-published.

Rehnborg, S. J., \& Moore, M., (2011) Maximising Volunteer Engagement. In T.D. Connors (Ed.), The Volunteer Management Handbook: Leadership Strategies for Success (2nd edition). New York, NY: Wiley.

Rhyne, R. (2009). Film festival circuits and stakeholders. In D. Iordanova and R. Rhyne (Eds.). Film Festival Yearbook 1: The Festival Circuit. St. Andrews, UK: St. Andrews Film Studies.

Rüling, C.-C., \& Pedersen, J.S. (2010). Film festival research from an organizational studies perspective. Scandinavian Journal of Management, 26(3), 318-323.

Ruoff, J. (2012). Coming Soon to a Festival Near You: Programming Film Festivals. St. Andrews, UK: St Andrews Film Studies.

Stepputat, A. (1995). Administration of volunteer programs, In T.D. Connors et al. (Eds.), The Volunteer Management Handbook. New York, NY: Wiley.

Stedman, N. (2004). Volunteer administration: Theoretical dimensions of the discipline, Journal of Leadership Education, 2(1).

Stringer, J. (2008) Genre films and festival communities: Lessons from Nottingham, 19912000. Film International, 6(4), 53-60.

VFF (2015) Valletta Film Festival Vision 2020 Plan. Film Grain Foundation. Internal document.

VFF (2017a) VFF Volunteer Code of Conduct. Film Grain Foundation. Internal document.

VFF (2017b) VFF Volunteer Handbook. Film Grain Foundation. Internal document.

Wong, C. H.-W. (2016). Publics and counterpublics: Rethinking film festivals as public spheres. In M. de Valck, B. Kredell, and S. Loist (Eds.), Film Festivals: History, Theory, Method, Practice. London, UK: Routledge. 
Wong, C. H.-W. (2011). Film Festivals: Culture, People, and Power on the Global Screen. New Brunswick, NJ: Rutgers University Press. 